\title{
Chironomidae (Diptera) species diversity of estuaries across a land use gradient on the Caribbean coast of Costa Rica
}

\author{
Petra Kranzfelder ${ }^{1,2 *} \&$ Leonard C. Ferrington, Jr. ${ }^{1}$ \\ 1. Department of Entomology, University of Minnesota, 1980 Folwell Avenue, 219 Hodson Hall, Saint Paul, MN 55108 \\ USA; ferri016@umn.edu \\ 2. Department of Biology Teaching and Learning, University of Minnesota, 3-133 Molecular Cellular Biology, 420 \\ Washington Avenue SE, Minneapolis, MN 55455 USA; kranz081@umn.edu \\ * Correspondence
}

Received 31-V-2018. C Corrected 13-VI-2018. Accepted 03-VII-2018.

\begin{abstract}
The family Chironomidae (Diptera) is the most widely distributed, most diverse, and often the most abundant of all families of benthic macroinvertebrates in aquatic ecosystems, including estuaries and other coastal marine ecosystems. Chironomid assemblages are likely to provide a useful measure of biotic integrity in estuaries of Costa Rica, which lack an intensive estuarine bioassessment tool to support environmental monitoring and regulatory programs. We characterized the taxonomic composition of Chironomidae, tested a Chironomidae Index of Biotic Integrity (CIBI) developed from extrinsic pollution tolerance values for its efficacy in evaluating the surface water quality and physical habitat, and made recommendations for increasing the sensitivity of the CIBI to detect differing degrees of stress across a range of estuaries in Costa Rica. Specifically, we selected nine estuaries within six different watersheds across a land use gradient located on the Caribbean coast of Costa Rica and collected Chironomidae surface-floating pupal exuviae (SFPE) samples biannually for two consecutive years (July 2012, Jan. 2013, July 2013, Jan. 2014). We identified 228 morphospecies and 70 genera from 17071 Chironomidae pupal exuviae collected from nine estuaries, which ranked in the following order from lowest to highest biotic integrity based on CIBI scores: Estero Negro, Laguna Cuatro, Laguna Jalova, Laguna del Tortuguero, Río Parismina, Laguna Barra del Colorado, Río Pacuare, Río Bananito, and Río Estrella. The CIBI successfully differentiated between estuaries with poor versus good biotic integrity, indicating that CIBI could be used to evaluate the surface water quality and physical habitat of Costa Rican estuaries. We recommend that future studies refine our approach by developing regionally accurate genus and corresponding species-level tolerance values to improve the sensitivity of the CIBI for biological monitoring of Costa Rican estuaries. Rev. Biol. Trop. 66(3): 1118-1134. Epub 2018 September 01.
\end{abstract}

Key words: Chironomidae Index of Biotic Integrity; Neotropical; water quality; biological monitoring; tolerance values; pupal exuviae.

During the past several decades, agricultural intensification has increased nutrient enrichment and caused widespread eutrophication, accelerating the flow of nutrients to estuaries and other coastal marine ecosystems (ECEs) (Bricker et al., 2008; Howarth et al., 2011; Kennish \& Townsend, 2007). Nutrient over-enrichment has been identified as the primary cause of water quality and habitat degradation of ECEs (Boesch et al., 2001; Nixon, 1995; Paerl, Hall, Peierls, \& Rossignol, 2014).
In tropical regions, land conversion of native rainforest ecosystems to monoculture plantation agriculture has posed significant risks to ECEs (Downing et al., 1999; Kress, Coto, Brenes, Brenner, \& Arroyo, 2002; Lovelock, Feller, McKee, Engelbrecht, \& Ball, 2004).

On the Caribbean coast of Costa Rica, banana and pineapple plantations are two types of agricultural land uses that impact ECEs (Castillo et al., 2006; Echeverría-Sáenz et al., 2012; Grant, Woudneh, \& Ross, 2013). 
Both types of monoculture agriculture are linked to water pollution via modifications in water movement through the construction of canals that channelize runoff, and application of large quantities of agrochemicals through aerial spraying and ground application (Castillo, de la Cruz, \& Ruepert, 1997; Castillo, Ruepert, \& Solis, 2000; Diepens et al., 2014; Pringle et al., 2016). In addition, the Caribbean coast of Costa Rica is experiencing urbanization by increasing the number of paved and improved gravel roads to accommodate the expansion of pineapple and banana plantations (Fagan, 2014). Kranzfelder, Corcoran, Rampi, Knight, and Ferrington (in review) found that expansion of agricultural plantations was the most pronounced land use change in the Northeastern Caribbean watersheds of Chirripo and Tortuguero, while urbanization was the most evident change in the south-central watersheds of Reventazón and Pacuare.

Biological multimetric indices, such as the Index of Biotic Integrity (IBI), are effective and efficient bioassessment tools that synthesize several community or individual level metrics into a numerical score in order to evaluate the cumulative impact of multiple stressors on the health of ECEs (Barbour, Gerritsen, Snyder, \& Stribling, 1999; Herman \& Nejadhashemi, 2015; Karr, 1981; Weisberg et al., 1997). Traditional multimetric IBI approaches have focused on periphyton, benthic macroinvertebrate, and fish assemblages (Barbour et al., 1999; Karr, 1981; Karr, Fausch, Angermeier, Yant, \& Schlosser, 1986). However, the family Chironomidae (Diptera), commonly referred to as non-biting midges or chironomids, is the most widely distributed, most diverse, and often the most abundant of all families of benthic macroinvertebrates in aquatic ecosystems, including ECEs (Ferrington Jr., 2008). Chironomid communities are considered valuable bioindicators of water quality due to their high species diversity and the varying sensitivity of these species to land use changes, including urbanization, agriculture, and deforestation, and subsequent nutrient enrichment (King \& Richardson, 2002; Lunde \& Resh, 2012;
Nicacio \& Juen, 2015; Rosenberg, 1992; Ruse, 2010; Thorne \& Williams, 1997). There are nearly 900 species described from the Neotropical Region (Spies, Andersen, Epler, \& Watson, 2009; Spies \& Reiss, 1996), and up to 20000 species may exist worldwide (Ferrington Jr., 2008). In addition, chironomids are among the few aquatic insect families that have adapted to live in a wide range of salinities, from 0 to $35 \mathrm{ppt}$, and can be a major component of the fauna of brackish waters (Cañedo-Argüelles et al., 2012; Casas \& Vilchez-Quero, 1996; Dimitriadis \& Cranston, 2007; James, Cant, \& Ryan, 2003; Williams \& Hamm, 2002; Williams \& Williams, 1998). For example, there are typical marine species, such as Clunio marinus Haliday, 1855 (Palmégn \& Lindeberg, 1959) or the flightless genus Pontomyia Edwards, 1926 (Huang \& Cheng, 2011). However, three predominately freshwater genera, Chironomus Meigen, Cricotopus v.d. Wulp, and Tanytarsus v.d. Wulp, have species in brackish water and are part of the marine fauna, as well (Colbo, 1996). In one brackish Costa Rican estuary, Laguna del Tortuguero, Kranzfelder and Ferrington Jr. (2016) identified 98 morphospecies with species diversity structured along a salinity gradient.

One low-cost, simple, and efficient method of assessing chironomid communities involves collections of Chironomidae surface-floating pupal exuviae (SFPE) (Ferrington Jr. et al., 1991; Kranzfelder et al., 2015; Wilson \& Ruse, 2005), which is the exoskeleton shed by the adult as it emerges on the surface of the water. SFPE accumulate behind obstructions, like fallen trees or along banks, through the action of wind or water current and can be collected to give a comprehensive sample of emerging chironomid communities for biological monitoring purposes (Kranzfelder et al., 2015). Collections of SFPE samples have many advantages over benthic samples of chironomid larvae including: (1) enhanced ease of sample processing and species identification, (2) more accurate estimates of the number of species collected in samples, (3) better collection from a range of microhabitats, including areas that 
are difficult to sample with other collection methods (e.g. wood, sand, and deep waters), and (4) improved measurement of how water quality characteristics influence biodiversity of aquatic systems, since SFPE collected represent individuals that have successfully completed their life cycle in that aquatic habitat (Bouchard Jr. \& Ferrington Jr., 2011).

In Costa Rica, the Biological Monitoring Working Party-Costa Rica (BMWP-CR) biotic index was adopted in the Executive Decree No. 33902-S-MINAE (Ministerio del Ambiente y Energia y la Ministra de Salud, 2007) for assessment of environmental quality of waters (Gutierrez-Fonseca \& Lorion, 2014; Maue \& Springer, 2008; Rizo-Patrón V, Kumar, McCoy Colton, Springer, \& Trama, 2013; Stein, Springer, \& Kohlmann, 2008). The BMWP-CR index value is based on the presence of macroinvertebrate families and their tolerance scores. According to their protocol, Chironomidae have a score of 2.0 and are categorized as being indicators of poor water quality. However, family identification does not provide sufficient resolution for sensitive and accurate bioassessments (Bailey, Norris, \& Reynoldson, 2001; Bouchard Jr. \& D. Huggins, 2005; Lenat \& Resh, 2001), since tolerance to pollution varies by genus (Ruse, 2002; Wilson \& Ruse, 2005), and frequently among species within a genus (King \& Richardson, 2002). For example, Cricotopus, Chironomus, and Dicrotendipes are generally tolerant of organic pollution, while Cladotanytarsus, Parametriocnemus, and Paralauterborniella are intolerant of organic pollution (Wilson \& Ruse, 2005). To provide better resolution of environmental quality for bioassessment, Chironomidae IBIs have been successfully developed for bioassessment of wadeable groundwater- and surface-water-dominated streams in Minnesota (Bouchard Jr. \& Ferrington Jr., 2011) and wadeable perennial streams in the Northern Glaciated Plains ecoregion (Kafle, 2013). Thus, Chironomidae assemblages may provide a useful measure of biotic integrity in estuaries of Costa Rica, which lack an intensive estuarine bioassessment tool to support environmental monitoring and regulatory programs.

The objectives of this research were to (1) characterize the taxonomic composition of Chironomidae, (2) test a Chironomidae Index of Biotic Integrity (CIBI) developed from extrinsic pollution tolerance values for its efficacy in evaluating the surface water quality and physical habitat, and (3) make recommendations for increasing the sensitivity of CIBI to detect differing degrees of stress across a range of ECEs on the Caribbean coast of Costa Rica.

\section{MATERIALS AND METHODS}

Sample area: We selected nine estuaries within six different watersheds across a land use gradient located on the Caribbean coast of Costa Rica (Table 1, Fig. 1). These six watersheds were selected to represent a land use gradient from mostly primary and secondary tropical rainforest to largely monoculture plantation agriculture (e.g. banana and/or pineapple). At the coastal city of Limon $\left(09^{\circ} 57\right.$ $\mathrm{N} \& 83^{\circ} 01 \mathrm{~W}$; elevation 5 masl) (Fig. 1), the mean monthly temperature is $25.9^{\circ} \mathrm{C}$ and the mean total monthly rainfall is $298.3 \mathrm{~mm}$. Mean total monthly precipitation is $436.1 \mathrm{~mm}$ over an average of 22 rainy days in July and 317.0 $\mathrm{mm}$ over an average of 19 rainy days in January (Instituto Meteorológico Nacional, 2016). See Kranzfelder et al. (in review) for a detailed description of the study area, land uses, and land covers of the six watersheds.

Data collection and sample processing: We collected data biannually for two consecutive years (July 2012, Jan. 2013, July 2013, Jan. 2014). We sampled each of the nine estuaries one day during each sample event. We collected data from three zones in each estuary that represent a range of estuarine conditions: (1) the transition of the river into the estuary (1-10 ppt), (2) the middle of the estuary (10-20 ppt), and (3) near the outlet of the estuary to the ocean (20-30 ppt). We collected Chironomidae SFPE samples along 500-1 000 meter reaches of the left and right descending banks 
TABLE 1

Costa Rica study watersheds, estuaries, GPS coordinates, percent forest land cover, and average physiochemical parameters of the water

\begin{tabular}{|c|c|c|c|c|c|c|c|}
\hline Watershed & Estuary & Coordinates & $\%$ Forest & Water temp. & DO & Salinity & Secchi \\
\hline Chirripo & Laguna Barra del Colorado & $10^{\circ} 45^{\prime} 54^{\prime \prime} \mathrm{N} \&-83^{\circ} 29^{\prime} 31^{\prime \prime} \mathrm{W}$ & 73.3 & 26.4 & 6.3 & 0.1 & 0.3 \\
\hline Tortuguero & Laguna Cuatro & $10^{\circ} 37^{\prime} 58^{\prime \prime} \mathrm{N} \&-83^{\circ} 32^{\prime} 44^{\prime \prime} \mathrm{W}$ & 53.7 & 26.4 & 1.7 & 7.0 & 1.1 \\
\hline Tortuguero & Laguna del Tortuguero & $10^{\circ} 33^{\prime} 30^{\prime \prime} \mathrm{N} \&-83^{\circ} 30^{\prime} 45^{\prime \prime} \mathrm{W}$ & 53.7 & 26.8 & 4.7 & 13.0 & 0.9 \\
\hline Tortuguero & Laguna Jalova & $10^{\circ} 20^{\prime} 51^{\prime \prime} \mathrm{N} \&-83^{\circ} 23^{\prime} 42^{\prime \prime} \mathrm{W}$ & 53.7 & 26.1 & 5.5 & 2.0 & 0.5 \\
\hline Reventazón & Río Parismina & $10^{\circ} 18^{\prime} 29^{\prime \prime} \mathrm{N} \&-83^{\circ} 21^{\prime} 19^{\prime \prime} \mathrm{W}$ & 57.9 & 25.5 & 7.1 & 0.1 & 0.2 \\
\hline Pacuare & Río Pacuare & $10^{\circ} 23^{\prime} 12^{\prime \prime} \mathrm{N} \&-83^{\circ} 17^{\prime} 21^{\prime \prime} \mathrm{W}$ & 75.8 & 25.4 & 7.0 & 0.4 & 0.5 \\
\hline Bananito & Río Bananito & $9^{\circ} 52^{\prime} 42^{\prime \prime} \mathrm{N} \&-82^{\circ} 57^{\prime} 43^{\prime \prime} \mathrm{W}$ & 85.4 & 26.4 & 6.1 & 3.9 & 0.6 \\
\hline Bananito & Estero Negro & $9^{\circ} 50^{\prime} 45^{\prime \prime} \mathrm{N} \&-82^{\circ} 56^{\prime} 12^{\prime \prime} \mathrm{W}$ & 85.4 & 27.5 & 3.0 & 9.8 & 0.5 \\
\hline Estrella & Río Estrella & $9^{\circ} 47^{\prime} 09^{\prime \prime} \mathrm{N} \&-82^{\circ} 53^{\prime} 29^{\prime \prime} \mathrm{W}$ & 91.0 & 24.7 & 7.2 & 3.4 & 0.3 \\
\hline
\end{tabular}

Coordinates $=$ GPS coordinates in middle zone of estuary sample area, $\%$ Forest $=$ percent forest land cover per watershed (data from Kranzfelder et al. (in review)), Water temp. = average water temperature $\left({ }^{\circ} \mathrm{C}\right), \mathbf{D O}=$ average dissolved oxygen $(\mathrm{mg} / \mathrm{L})$, Salinity $=$ average salinity $(\mathrm{ppt})$, Secchi $=$ average Secchi depth $(\mathrm{m})$.

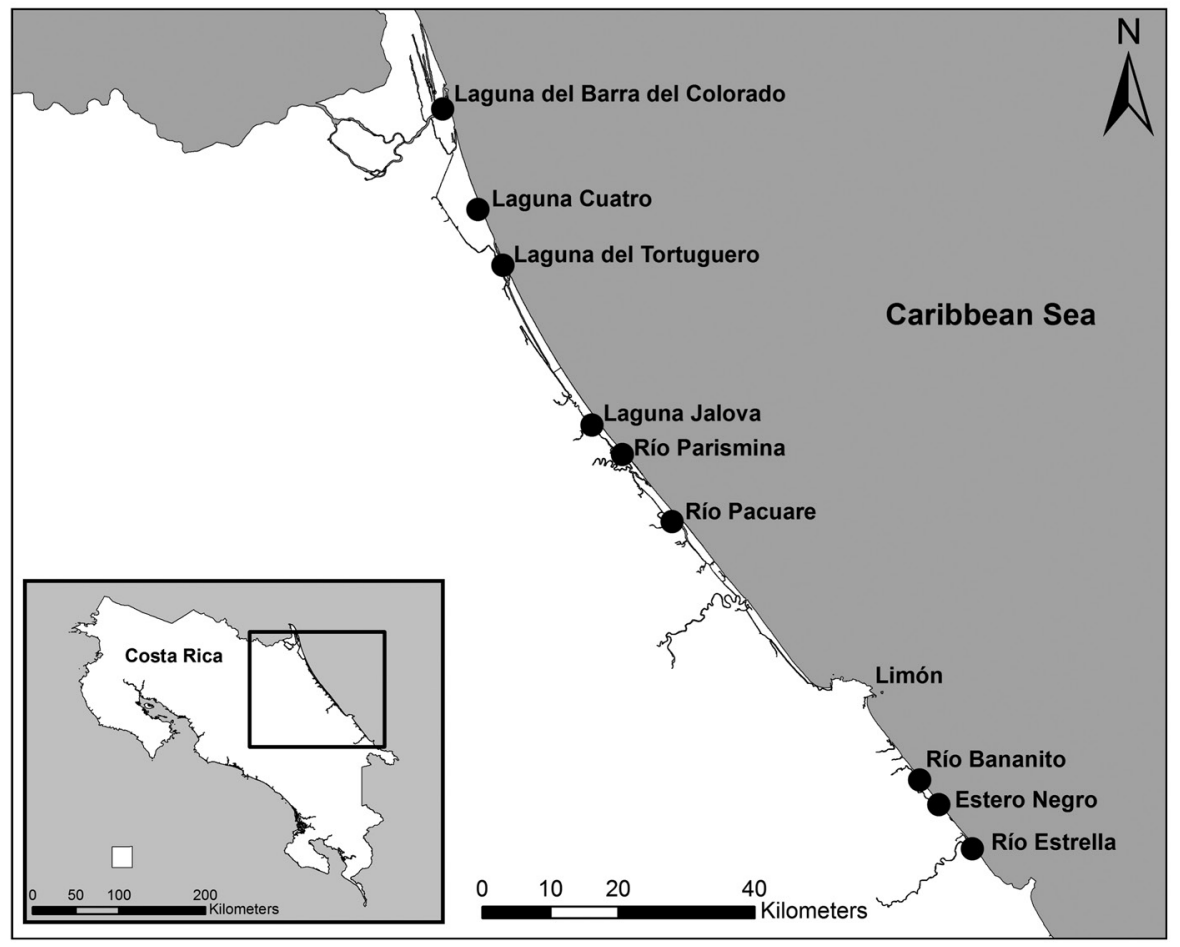

Fig. 1. Locations of nine estuaries on the Caribbean coast of Costa Rica. Black dot indicates location of sample estuary.

at each sample zone. We used a YSI Pro2030 field dissolved oxygen/conductivity handheld meter to measure the following physiochemical parameters from each zone: water temperature, dissolved oxygen, and salinity. A Secchi disk was used to measure water clarity using standard protocol described by (Shapiro, Lamarra, \& Lynch (1975) (Table 1).

Chironomidae SFPE samples were collected from both banks of each zone to account 
for hourly-to-daily changes in wind and tidal pattern, which may affect the down water drift of chironomid pupal exuviae. We collected 24 SFPE samples per estuary ( 3 zones x 2 SFPE samples/zone x 4 sample events) and followed methods described by Kranzfelder et al. (2015), except samples were collected for $20 \mathrm{~min}$ instead of $10 \mathrm{~min}$, as suggested by Siqueira, De Oliveira Roque, and Trivinho-Strixino (2008) and Kranzfelder and Ferrington Jr. (2016). Briefly, we collected SFPE samples by repeatedly dipping a white plastic tray into areas of known SFPE accumulation (e.g. behind a fallen tree) and pouring then contents from the tray through a $125-\mu \mathrm{m}$-aperture US Standard test sieve to retain chironomid SFPE and residue. We transferred the sample to $60-\mathrm{ml}$ jars and preserved with $95 \%$ ethanol.

For each estuary, we picked up to 500 specimens per sample, but did not pick whole pupae, SFPE with adults still attached to the pupal exuviae, or broken specimens with less than $3 / 4$ of the specimen complete to avoid species identification problems. In temperate streams, a subsample size of 300 specimens was on average sufficient to identify a large proportion $(85 \%)$ of the Chironomidae community (Bouchard Jr. \& Ferrington Jr., 2011). However, the larger subsample size was chosen to ensure that SFPE samples represent a large proportion of the Chironomidae community from the relatively unknown ecosystem of Costa Rican estuaries. We dehydrated specimens in $95 \%$ ethanol before dissecting and slide mounting all specimens in Euparal. Specimens were either slide-mounted individually or in multiples. Slide-mounted specimens were identified under a compound scope to morphospecies or the lowest taxonomic level possible. All contemporary references were checked, but the following were especially useful: Beck and Beck (1966), Boesel (1974), Paggi (1977), Roback (1980), Roback and Coffman (1983), Borkent (1984), Sawedal (1984), Wiederholm (1986), Roback (1986), Soponis (1987), Epler (1988), Langton (1991), Caldwell (1993), Sublette and Sasa (1994), Serrano and Nolte (1996), Wiedenbrug and Fittkau (1997), Epler and Janetzky (1998), Hestenes and Saether (2000), Jacobsen and Perry (2000), Andersen and Mendes (2002), Wiedenbrug and Andersen (2002), Mendes, Marcondes, and Pinho (2003), Sæther (2004), Wiedenbrug and Ospina-Torres (2005), Ekrem (2007), Ferrington Jr., Berg, and Coffman (2008), Jacobsen (2008), Tejerina and Paggi (2009), Wiedenburg, Mendes, Pepinelli, and Trivinho-Strixino (2009), Wiedenburg and Trivinho-Strixino (2009), Oliveira, Mendes, and Silva (2010), Trivinho-Strixino, Da Silva, and Roque (2010), Ferrington Jr. and Saether (2011), Oliveira and Silva (2011), Saether (2011), Wiedenburg and TrivinhoStrixino (2011), Kranzfelder (2012), Sæther and Cranston (2012), Wiedenbrug, Lamas, and Trivinho-Strixino (2012), De Oliveira, Da Silva, and Gessner (2013), Wiedenburg, Lamas, and Trivinho-Strixino (2013), Da Silva, Fonseca-Gessner, and Ekrem (2014), Donato, Siri, Massaferro, and Brooks (2015), Silva and Ekrem (2016), and Tang (2016). Finally, we deposited voucher specimens in the insect collections at the University of Minnesota (UMSP) and University of Costa Rica (UCR). A list of species can be found in Supplemental Table 1 and a count of individuals by species in Supplemental Table 2.

Data analysis: We pooled 24 chironomid SFPE samples for each of the nine estuaries.

First, we estimated theoretical species richness in EstimateS with the abundancebased Chao 1 classic richness estimator (Eq. $1)$, which is a nonparametric species-richness estimator that takes into account relative abundance and performs well on data that include many rare species (Chao, 1984; Colwell, 2013):

$$
\mathrm{S}_{\text {est }}=\mathrm{S}_{\text {obs }}+\mathrm{a}^{2} / 2 \mathrm{~b}
$$

where $\mathrm{S}_{\mathrm{obs}}=$ the number of observed species in the sample; $\mathrm{a}=$ the number of species represented by only 1 individual; and $\mathrm{b}=$ the number of species represented by 2 individuals. Second, based on recommendations by Bouchard Jr. and Ferrington Jr. (2011) for Minnesota streams, we tested a Chironomidae Index of Biotic Integrity (CIBI) using 10 community 
TABLE 2

Ten community composition metric and diversity and biotic index values for each estuary

\begin{tabular}{lcccccccccc}
\multicolumn{1}{c}{ Estuary } & \% Orth & \% Chir & \% Tany & $\%$ Tol & \% Intol & richness & Berger & Shannon & Margalef & HBI \\
Laguna Barra del Colorado & 58.0 & 34.7 & 4.3 & 11.1 & 0.0 & 74 & 0.38 & 2.38 & 9.27 & 5.74 \\
Laguna Cuatro & 2.3 & 57.2 & 38.3 & 28.0 & 8.0 & 45 & 0.24 & 2.67 & 6.60 & 6.33 \\
Laguna del Tortuguero & 8.5 & 13.4 & 70.1 & 18.8 & 9.4 & 72 & 0.64 & 1.89 & 9.31 & 6.63 \\
Laguna Jalova & 10.5 & 35.1 & 49.0 & 22.2 & 3.7 & 55 & 0.44 & 2.22 & 7.52 & 5.17 \\
Río Parismina & 46.8 & 46.5 & 4.6 & 9.5 & 9.5 & 38 & 0.42 & 2.00 & 5.32 & 5.92 \\
Río Pacuare & 26.5 & 64.2 & 8.0 & 13.2 & 5.3 & 84 & 0.18 & 3.04 & 10.85 & 6.23 \\
Río Bananito & 21.9 & 39.5 & 33.3 & 20.9 & 2.3 & 109 & 0.15 & 3.38 & 13.43 & 6.54 \\
Estero Negro & 2.1 & 72.6 & 12.8 & 23.1 & 0.0 & 26 & 0.56 & 1.71 & 4.13 & 6.62 \\
Río Estrella & 27.0 & 13.4 & 29.0 & 14.0 & 7.0 & 120 & 0.14 & 3.37 & 14.52 & 6.83 \\
\hline
\end{tabular}

$\%$ Orth $=\%$ Orthocladiinae, $\%$ Chir $=\%$ Chironomini, $\%$ Tany $=\%$ Tanytarsini, $\%$ Tol $=\%$ Tolerance, $\%$ Intol $=\%$ Intolerant, richness $=$ total species richness, Berger $=$ Berger-Parker Index, Shannon $=$ Shannon's Index, Margalef $=$ Margalef's Index, HBI = Hilsenhoff's Biotic Index.

composition and diversity and biotic index metric values: Total Species Richness, BergerParker Index of Dominance (Eq. 2), Shannon's Diversity Index (Eq. 3), and Margalef's Diversity Index (Eq. 4), Hilsenhoff's Biotic Index (Eq. 5), \% Tolerant Genera, \% Intolerant Genera, \% Orthocladiinae, \% Chironomini, and \% Tanytarsini. Although these benthic metrics were regionally developed, they are effective at measuring a response across a range of human influence over a wide geographic area (Barbour et al., 1999). Metric values are the raw numeric expression of taxonomic or autecological information at either the community of individual level. Metric scores were derived from our metric values by calculating the metric value range (minimum to maximum) and ranking these values from 1 to 10 points based on its response to human disturbance. Metric values that respond negatively to human disturbance will have metric scores positively correlated to metric values, while metric values that respond positively to human disturbance will have metric scores inversely related to metric values (Barbour et al., 1999). The CIBI score was calculated for each estuary by summing the ten metric scores. See Supplemental Table S3 for a detailed description of each of the ten metrics. Using this approach, theoretical CIBI scores for each estuary range from 10 to 100 with lower CIBI scores indicating lower biotic integrity ratings and implying higher human disturbance. Estuary biotic integrity was rated in the following manner, similar to Karr et al. (1986): 1) Very poor: 10-19 CIBI score; 2) Poor: 20-39 CIBI score; 3) Fair: 40-59 CIBI score; 4) Good: 60-79; 5) Excellent: 80-100. Berger-Parker Index of Dominance was calculated as:

$$
D B P=n_{\max } / N
$$

where $n_{\max }=$ the number of specimens for the most common species and $N=$ the total number of specimens in the sample (Berger \& Parker, 1970; Magurran \& McGill, 2011). Shannon's Diversity Index was calculated as:

$$
H^{\prime}=-\sum\left(n_{i} / N\right) \ln \left(n_{i} / N\right)
$$

where $n_{i}=$ the number of specimens for the $i$ th species and $N=$ the total number of specimens in the sample (Magurran \& McGill, 2011). Margalef's Diversity Index was calculated as:

$$
D M G=(S-1) / \ln N
$$

where $S=$ total number of species in the pooled sample and $N=$ total number of specimens in the sample. Hilsenhoff's Biotic Index was calculated as:

$$
H B I=\left(\sum n_{i} T_{i}\right) / N
$$

where $n_{i}=$ the number of specimens for the $i$ th genus; $T_{i}=$ the tolerance value for the $i$ th genus; and $N=$ the total number of specimens in the sample (Hilsenhoff, 1977; Hilsenhoff, 
1987). We derived Holarctic pollution tolerance values for Chironomidae used in the HBI from Barbour et al. (1999) and Ferrington Jr. et al. (2008) (Table S4), because tolerance values are not available for Costa Rica. When available, we used Southeast United States genus values, but for cases where these values were not provided, we used tribe or subfamily values. Percent tolerant genera were calculated as the total genera out of all genera in the pooled samples with a tolerance value above 7. Percent intolerant genera were calculated as the total genera out of all genera with tolerance values below 3 .

\section{RESULTS}

We identified 228 morphospecies and 70 genera from 17071 pupal exuviae contained in the samples. Most of the morphospecies (220) and 14 genera are either undescribed or unknown for the pupal life stage. Tanytarsus was the most species-rich genus with 24 morphospecies followed by Polypedilum with
19 morphospecies and Cricotopus with 13 morphospecies (Table S1). The taxa collected included members from five subfamilies/tribes: Pseudochironomini (1.3\%), Tanypodinae (3.5 $\%)$, Orthocladiinae (26.8\%), Tanytarsini (28.4 $\%$ ), and Chironomini (40.1\%). Chironomini had the highest genus richness ranging from 5 to 21 genera per estuary and was followed by Orthocladiinae with 4 to 11 genera per estuary. Pseudochironomi was represented by the lowest genus richness with one genus: Pseudochironomus. The five most abundant genera, Tanytarsus (20.0\%), Nanocladius (14.1 $\%)$, Polypedilum (12.9\%), Cricotopus (9.5 $\%$ ), and Cladotanytarsus (5.8\%), collectively accounted for $62 \%$ of all specimens present in the samples (Table S2).

Río Estrella had the highest species richness, genus richness, and relative abundance $(120,43$, and 3620 , respectively). Estero Negro had the lowest species richness, genus richness, and relative abundance $(26,13,423$, respectively) (Fig. 2). Species-accumulation curves reached saturation for Laguna Cuatro,

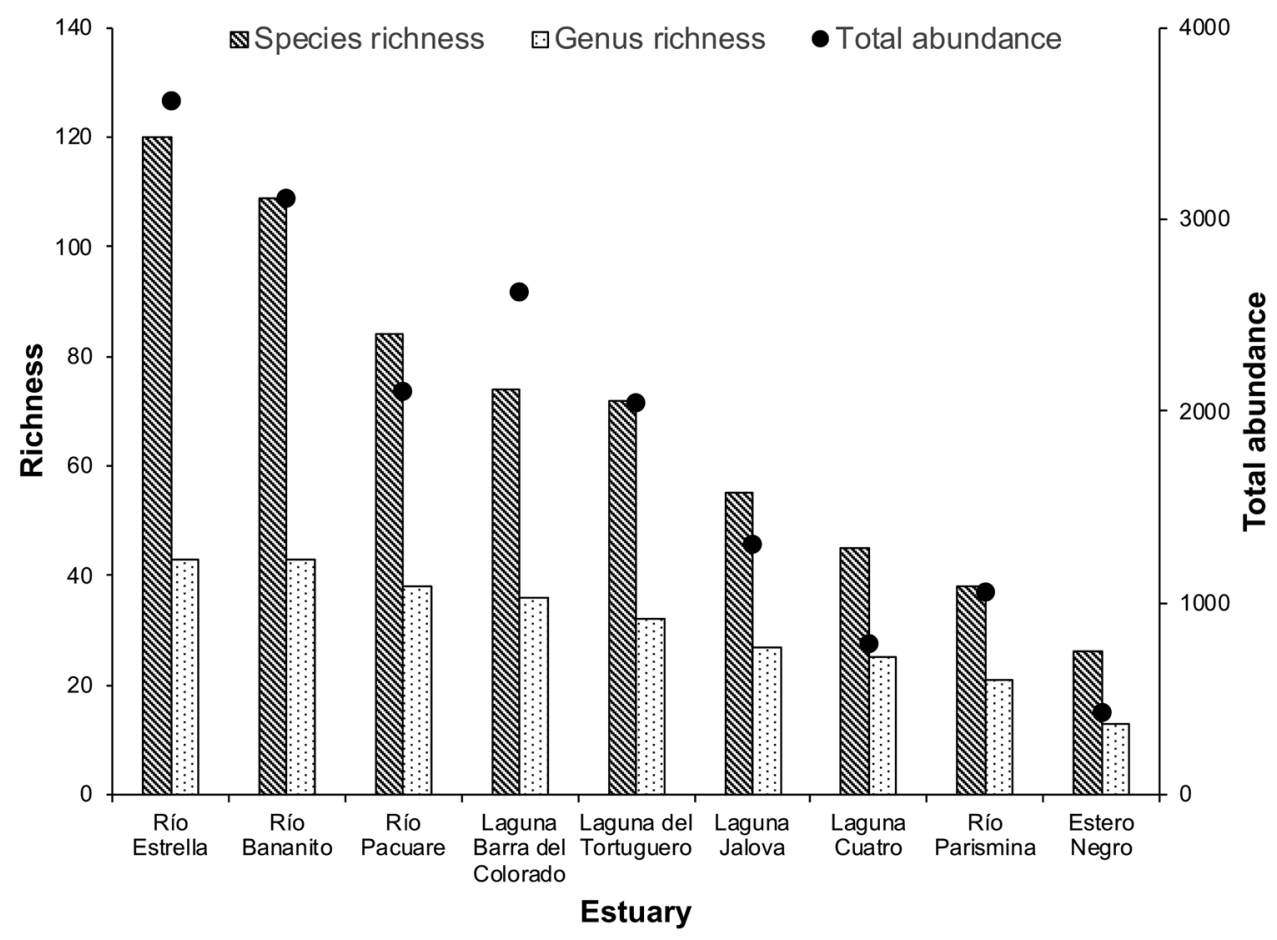

Fig. 2. Species and genus richness and total abundance of pupal exuviae samples from nine estuaries. 
Laguna del Tortuguero, Río Bananito, and Estero Negro with an average of $80.1 \%$ of estimated species collected. However, Laguna Barra del Colorado, Laguna Jalova, Río Parismina, Río Pacuare, and Río Estrella did not reach saturation with an average of $59.7 \%$ of estimated species collected (Fig. 3).

Chironomidae tolerance values ranged from 1.7 to $10(\overline{\mathrm{x}}=6.2)$ (Table S4). Percent Orthocladiinae ranged from $2.1 \%$ to $58.0 \%$, percent Chironomini from $13.4 \%$ to $72.6 \%$, percent Tanytarsini from $4.3 \%$ to $70.1 \%$, percent tolerant genera from $9.5 \%$ to $28.0 \%$, and percent intolerant genera from $0.0 \%$ to $9.5 \%$. Total species richness ranged from 26 to 120 , Berger-Parker Index of Dominance from 0.136 to 0.636 , Shannon's Diversity Index ranged 1.71 to 3.38 , Margalef's Diversity Index from 4.13 to 14.52, and Hilsenhoff's Biotic Index from 5.17 to 6.83 (Table 2). Río Bananito and Río Estrella scored the highest and Estero Negro the lowest on the following four Chironomidae assemblage metrics: Total Species
Richness, Berger-Parker Index of Dominance, Margalef's Diversity Index, and Shannon's Diversity Index. The estuaries ranked in the following order from lowest to highest biotic integrity based on CIBI scores: Estero Negro (15), Laguna Cuatro (44), Laguna Jalova (49), Laguna del Tortuguero (51), Río Parismina (51), Laguna Barra del Colorado (57), Río Pacuare (59), Río Bananito (61), and Río Estrella (71) (Table 3). The five most abundant genera for the lowest CIBI score (Estero Negro) were as follows: Polypedilum, Tanytarsus, Labrundinia, Dicrotendipes, and Cricotopus. The five most abundant genera for the highest CIBI score (Río Estrella) were as follows: Tanytarsus, Cricotopus, Polypedilum, Cladotanytarsus, and Cryptochironomus (Table S2).

\section{DISCUSSION}

Typically, chironomids are neglected in biological monitoring of estuarine and coastal
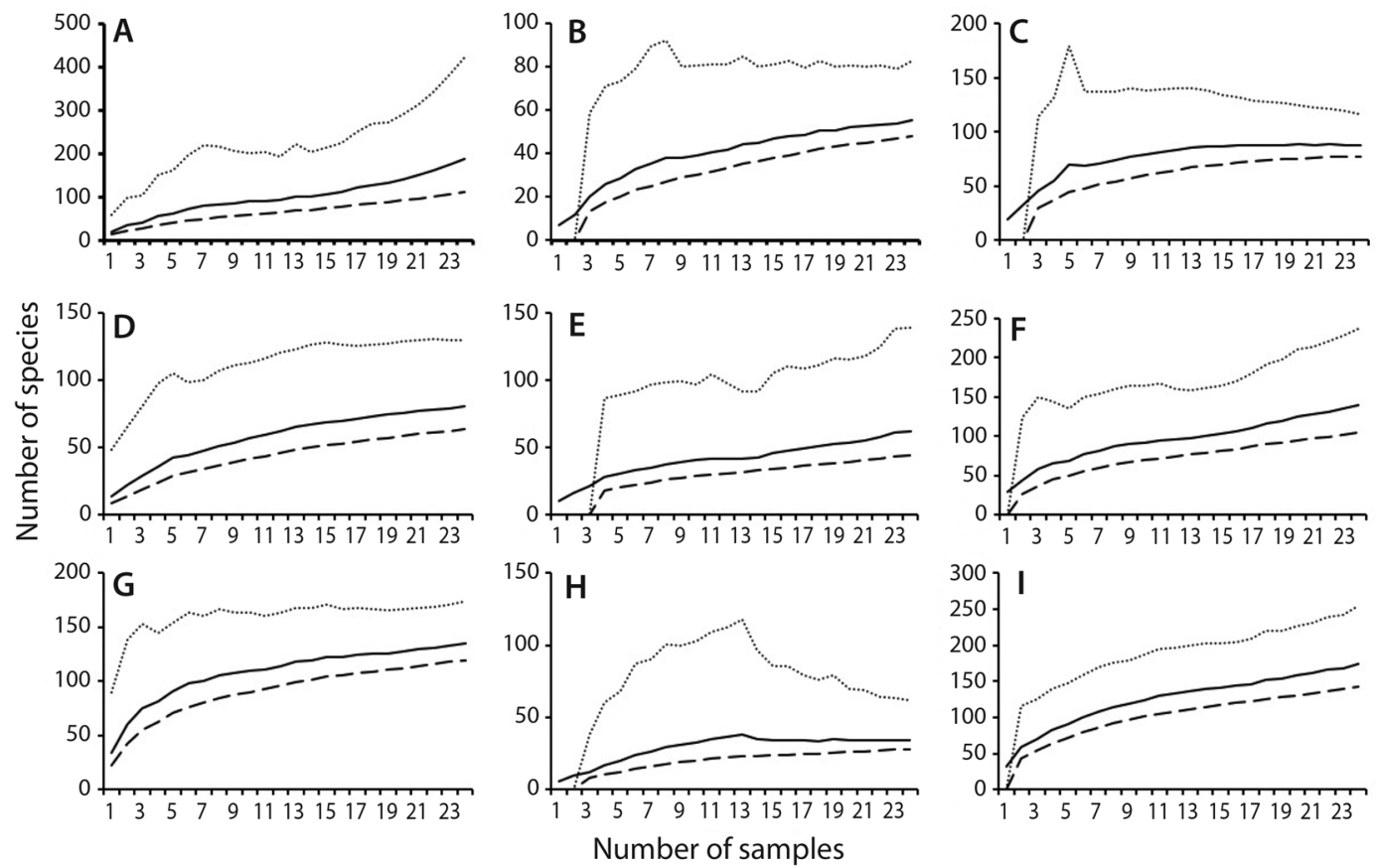

Fig. 3. Species accumulation curves for (A) Laguna Barra del Colorado; (B) Laguna Cuatro; (C) Laguna del Tortuguero; (D) Laguna Jalova; (E) Río Parismina; (F) Río Pacuare; (G) Río Bananito; (H) Estero Negro; (I) and Río Estrella. Solid black line indicates mean Chao 1 species-richness estimator and dotted and dashed black lines indicate Chao 1 upper and lower $95 \%$ confidence level, respectively. 
TABLE 3

Ten metric scores for each estuary

\begin{tabular}{|c|c|c|c|c|c|c|c|c|c|c|c|}
\hline Estuary & $\%$ Orth & $\%$ Chir & $\%$ Tany & $\%$ Tol & $\%$ Intol & richness & Berger & Shannon & Margalef & HBI & CIBI \\
\hline Laguna Barra del Colorado & 10 & 7 & 1 & 10 & 1 & 6 & 6 & 4 & 5 & 7 & 57 \\
\hline Laguna Cuatro & 1 & 3 & 6 & 1 & 8 & 3 & 9 & 6 & 3 & 4 & 44 \\
\hline Laguna del Tortuguero & 1 & 10 & 10 & 6 & 9 & 5 & 1 & 2 & 5 & 2 & 51 \\
\hline Laguna Jalova & 2 & 7 & 7 & 4 & 4 & 4 & 4 & 3 & 4 & 10 & 49 \\
\hline Río Parismina & 8 & 5 & 1 & 10 & 10 & 2 & 5 & 2 & 2 & 6 & 51 \\
\hline Río Pacuare & 5 & 2 & 1 & 9 & 6 & 7 & 10 & 8 & 7 & 4 & 59 \\
\hline Río Bananito & 4 & 6 & 5 & 4 & 2 & 9 & 10 & 10 & 9 & 2 & 61 \\
\hline Estero Negro & 1 & 1 & 2 & 3 & 1 & 1 & 2 & 1 & 1 & 2 & 15 \\
\hline Río Estrella & 5 & 6 & 4 & 8 & 7 & 10 & 10 & 10 & 10 & 1 & 71 \\
\hline
\end{tabular}

$\%$ Orth $=\%$ Orthocladiinae, $\%$ Chir $=\%$ Chironomini, $\%$ Tany $=\%$ Tanytarsini, $\%$ Tol $=\%$ Tolerance, $\%$ Intol $=\%$ Intolerant, richness $=$ total species richness, Berger $=$ Berger-Parker Index, Shannon = Shannon's Index, Margalef = Margalef's Index, Hilsenhoff = Hilsenhoff's Biotic Index, CIBI = Chironomidae Index of Biotic Integrity score.

ecosystems (ECEs) since species have been reported to typically prefer low salinities and are generally considered freshwater organisms (Pinder, 1986; Williams, 1998). The 228 morphospecies from 70 genera and five subfamilies/tribes demonstrates that rich chironomid communities are not only present in these Costa Rican estuaries, but that species richness was high, similar to results in Kranzfelder and Ferrington Jr. (2016). Putting these results into context, we detected the equivalent of $154 \%$ of the reported 148 species of chironomids reported by Watson and Heyn (1992) during their extensive collections from lotic Costa Rican habitats, ranging from small springs to large rivers, and the equivalent of $85 \%$ of the reported 266 species of chironomids collected from 13 streams in northwestern Costa Rica (Coffman, de la Rosa, Cumming, \& Wilzbach, 1992). Dimitriadis and Cranston (2007) recorded 44 species from 5735 chironomid larvae collected from an Australian estuary, fewer than the number of species recorded from seven out of the nine estuaries in our study.

Species-accumulation curves reached saturation for four estuaries, including Laguna Cuatro, Laguna del Tortuguero, Río Bananito, and Estero Negro. Therefore, these results suggest that these estuaries, especially Estero Negro, were sufficiently sampled and our results are based on biotic responses, not differences in sampling effort. However, the speciesaccumulation curves did not reach saturation for five estuaries, including Laguna Barra del Colorado, Laguna Jalova, Río Parismina, Río Pacuare, and Río Estrella. These five estuaries have moderate to high species richness and abundance. However, it is common for species accumulation curves from sampling to not reach an asymptote in the tropics since species diversity is high and most species are rare. For example, after nearly 30 consecutive years of sampling, an ongoing inventory of a tropical rainforest ant assemblage at La Selva, Costa Rica, has still not reached an asymptote in species richness and tropical biodiversity studies often fall short of revealing the complete species richness for an assemblage (Gotelli \& Colwell, 2011). While undetected species remain in these estuaries, we argue that our main results are based on the common species detected. However, we predict that more extensive sampling in these Costa Rican estuaries would further widen the observed species richness gap between the least and most species rich estuaries.

While we collected a high number of species in this study, 125 species were represented by less than 10 specimens, indicating a large number of rare species with low abundances. 
This pattern is consistent with other Neotropical studies involving chironomids (Coffman \& de la Rosa, 1998; Ferrington Jr., Buzby, \& Masteller, 1993; Pringle \& Hamazaki, 1998; Souza, Moulton, Silveira, Krsulovic, \& Brito, 2007). Coffman and de la Rosa (1998) reported low chironomid densities of less than 5000 larvae per square meter in Northwestern Costa Rican streams, compared to larval densities ranging up to 50000 larvae per square meter reported in temperate areas (Lindegaard, 1989). Presence of filter-feeding shrimp or predatory benthic macroinvertebrates and fish could account for the low abundance of chironomids in our study estuaries. Ferrington Jr. et al. (1993) collected 2451 chironomids from a Puerto Rican stream over the course of one year, and suggested that filter-feeding shrimp could compete with and decrease the number of filter-feeding chironomid genera, like Rheotanytarsus. Pringle and Hamazaki (1998) found that omnivorous fish and shrimp reduced chironomid larval densities in lowland streams of Northeastern Costa Rica.

Our results indicate that the CIBI we have developed can be used to evaluate the surface water quality and physical habitat of Costa Rican estuaries. Individual metrics are derived from an extrinsic model and thus provide a high degree of objectivity to the CIBI. Structed in this manner, the CIBI successfully differentiated between estuaries with very poor biotic integrity (Estero Negro), estuaries with fair biotic integrity (Laguna Cuatro, Laguna Jalova, Laguna del Tortuguero, Río Parismina, Laguna Barra del Colorado, Río Pacuare), and estuaries with high biotic integrity (Río Bananito and Río Estrella).

These results, based on biotic data, follow the same patterns observed in our study based on coastal watershed land cover data, except Estero Negro (Kranzfelder et al., in review). In that study, we ranked watersheds in the following order from most to least impacted by human land use change, and thus, susceptible to water quality issues: Tortuguero, Reventazón, Chirripo, Pacuare, Bananito, and Estrella (Kranzfelder et al., in review). Estero Negro is in the Bananito watershed; and therefore, based on the land use composition, we would predict high biotic integrity, similar to Río Bananito and Río Estrella. However, on average, Estero Negro had low dissolved oxygen $(3.0 \mathrm{mg} / \mathrm{L})$ and moderate salinity (9.8 ppt) compared to the estuaries with higher biotic integrity (Table 1). The low dissolved oxygen could be due to high organic matter in the estuary from decomposition of plants or animals and the moderate salinity could indicate a tidally influenced estuary. We believe that for this estuary small-scale environmental factors (i.e., low dissolved oxygen and moderate salinity) had a greater impact on the taxonomic composition of the chironomid community than cumulative coastal watershed land use.

Four metrics showed a large range in scores between the estuary with the highest water quality (Río Estrella) and estuary with the lowest water quality (Estero Negro): Total Species Richness, Berger-Parker Index of Dominance, Margalef's Diversity Index, and Shannon's Diversity Index. These four metrics were calculated using the species richness and relative abundance of chironomids in the samples. Therefore, Río Estrella had the highest species richness and relative abundance and scored the highest CIBI score. By contrast, the other six metrics, which are based on the relative abundances of different tribes, relative abundance of tolerant/intolerant genera using literature-based tolerance values, and abundance-weighted average of each genus using tolerance values, did not show as large a range in scores or inconsistent scores between the estuaries with lowest and highest water quality. This was especially evident when we used extrinsic genus-level values for Polypedilum for our initial trials related to the HBI metric. For instance, genus-level tolerance resulted in the lowest HBI score for Rio Estrella, which otherwise had moderate-to-maximum score for the other nine metrics. On closer inspection, we realized that the numerically dominant species of Polypedilum in the estuary differed from numerically dominant species of Polypedilum in the low-ranking estuaries. 
In addition to the HBI metric, the remaining tribe- and genus-based metrics did not closely follow the trends of the four speciesbased metrics. Even though the 70 genera collected have a wide range of generic pollution tolerances from very intolerant (1.7) to very tolerant (10), our results suggest that there are likely to be some additional genera for which species-level differences to pollution should not be generalized by using generic tolerance values. For example, Cladotanytarsus has a tolerance value of 3.7 based on extrinsic data and was very abundant in samples from both Río Estrella and Laguna Jalova. Recent research in Minnesota on lakes with differing trophic states has revealed that different species of Cladotanytarsus occur in oligotrophic versus hypereutrophic lakes (Ferrington, unpublished data) and should be given different tolerance values. Subsequently, differing intrinsic species tolerances for this genus may need to be developed for use in the estuarine CIBI. For example, Laguna Jalova had a higher number of individuals from this genus than Río Estrella; and so, Laguna Jalova had an HBI score of 10, while Río Estrella had an HBI score of only 3. However, the Cladotanytarsus present in Laguna Jalova was a different species than Río Estrella. Based on the land use in the Tortuguero watershed with $10.4 \%$ forest land cover and $28.3 \%$ pasture cover, we predict that the Cladotanytarsus sp. present in Laguna Jalova is likely to be highly tolerant of organic enrichment and should have been assigned a higher intrinsic tolerance value than 3.7.

While most species were rare, there were three species-rich and abundant genera, Cricotopus, Polypedilum, and Tanytarsus, which accounted for $42.4 \%$ of the total abundance in the samples. Cricotopus and Polypedilum were collected from all nine estuaries and Tanytarsus was collected from all estuaries except Río Parismina. We recommend that future Costa Rican estuarine biomonitoring studies focus on assessment of individual morphospecies within these three genera and use measurement of specific stressors, like nitrogen and phosphorus, to develop more realistic intrinsic tolerance values of these morphospecies of estuaries of Costa Rica. For example, the species-rich genus Cricotopus has some species within subgenus Cricotopus and subgenus Isocladius that are resistant to many forms of pollution, while there are some species within subgenus Nostococladius that are not resistant to many forms of pollution (Wilson \& Ruse, 2005). For genus Polypedilum in the Southeast USA, Polypedilum aviceps has a tolerance value of 4.0, while Polypedilum illinoense has a tolerance value of 9.2 (Barbour et al., 1999) and it can be expected that ranges in tolerance among species in Costa Rica will have similar magnitude.

Thorne and Williams (1997) have argued that genus identifications of benthic macroinvertebrates for bioassessments in tropical countries are rarely possible and propose that use of family-level biotic indices, like the qualitative BMWP-CR (Biological Monitoring Working Party-Costa Rica), is more practical. However, based on our results, we suggest that a multimetric index of biotic integrity focused on Chironomidae at genus-level is useful for evaluating the integrity of ecologically important Costa Rican estuaries. We recommend that future studies evaluate and calibrate regionally accurate genus, and corresponding species-level tolerance values for Cricotopus, Polypedilum, Cladotanytarsus, and Tanytarsus using estuary-specific stressors, such as nutrient enrichment, in order to improve the sensitivity of the CIBI for use in biological monitoring of ECEs in Costa Rica. In addition, morphospecies can be given a described species name by either rearing immature life stages (eggs, larvae, or pupae) to adults with species descriptions (Spies et al., 2009) or using DNA barcodes to link pupal exuviae to described species using approaches refined by Kranzfelder, Ekrem, and Stur (2017).

\section{ACKNOWLEDGMENTS}

We would like to thank the Canadian Organization for Tropical Education and Rainforest Conservation, especially staff members Charlotte Foale and Manuel Arias, for assisting us in 
the research at Caño Palma Biological Station. Also, thanks to Jenna McCullough, Miranda Roberts, Katherine DeGuire, and Katherine Kemmitt for assistance with field and lab work in Costa Rica and the University of Minnesota. We thank Costa Rica's Ministerio del Ambiente y Energía for providing research permits (138-2012-SINAC, 207-2012-SINAC, 74-2013-SINAC, and SINAC-SE-GASP-PIR-001-2014) and export permits (DGVS-6212012, DGVS-027-2013, DGVS-333-2013, and DGVS-011-2014). We also give many thanks for the following funding sources that allowed this work to be completed: National Science Foundation (Grant No. 1114845), University of Minnesota's Global Programs and Strategy Alliance for the Master's, Professional, or Doctoral International Research Grant; University of Minnesota's Bell Museum of Natural History for the Dayton-Wilkie Natural History Fund; University of Minnesota's Graduate School for the Alexander and Lydia Anderson Fellowship and the Doctoral Dissertation Fellowship; and the University of Minnesota's Department of Entomology for the Morris and Elaine Soffer Rockstein Fellowship.

\section{RESUMEN}

Diversidad de especies de Chironomidae (Diptera) de estuarios en un gradiente de uso de suelo en la costa Caribe de Costa Rica. La familia Chironomidae (Diptera) es la más ampliamente distribuida, más diversa y a menudo, la más abundante de todas las familias de macroinvertebrados bentónicos en ecosistemas acuáticos, incluyendo estuarios y otros ecosistemas marinos. Probablemente, los ensambles de quironómidos proporcionen una medida útil de integridad biótica en estuarios de Costa Rica, los cuales carecen de una herramienta de evaluación biológica que respalde programas de monitoreo ambiental y programas regulatorios. Caracterizamos la composición taxonómica de Chironomidae, probamos un Índice de Integridad Biótica de Chironomidae (CIBI) desarrollado a partir de valores de tolerancia de contaminación extrínseca, por su eficacia en evaluar la calidad de la superficie del agua y el hábitat físico. Además, realizamos recomendaciones para incrementar la sensibilidad del CIBI para detectar diferentes grados de estrés en un rango de estuarios en Costa Rica. Específicamente, seleccionamos nueve estuarios dentro de seis cuencas diferentes a lo largo de un gradiente de uso de suelo en la costa Caribe de Costa Rica y recolectamos muestras de las exuvias pupales que flotan en la superficie
(SFPE) por dos años consecutivos (Julio 2012, Enero 2013, Julio 2013, Enero 2014). Identificamos 228 morfoespecies y 70 géneros de 17071 exuvias de pupas de Chironomidae recolectadas en nueve estuarios, los cuales se clasificaron en el siguiente orden de menor a mayor integridad biótica basado en los valores del CIBI: Estero Negro, Laguna Cuatro, Laguna Jalova, Laguna del Tortuguero, Río Parismina, Laguna Barra del Colorado, Río Pacuare, Río Bananito, y Río Estrella. El CIBI diferenció eficazmente entre estuarios con integridad biótica pobre versus buena, indicando que el CIBI puede ser usado para evaluar la calidad de la superficie del agua y el hábitat físico de estuarios de Costa Rica. Recomendamos que estudios futuros refinen nuestro planteamiento desarrollando valores de tolerancia de géneros precisos regionalmente y niveles correspondientes de especies para mejorar la sensibilidad del CIBI para el monitoreo de estuarios de Costa Rica.

Palabras clave: Índice de Integridad Biótica de Chironomidae; neotropical; calidad de agua; monitoreo biológico; valores de tolerancia; exuvias pupales.

\section{REFERENCES}

Andersen, T., \& Mendes, H. F. (2002). New species and records of the Axarus "rogersi-group" from South and Central America (Diptera, Chironomidae). Acta Zoologica Academiae Scientiarum Hungaricae, 48(1), 34-40.

Bailey, R. C., Norris, R. H., \& Reynoldson, T. B. (2001). Taxonomic resolution of benthic macroinvertebrate communities in bioassessments. Journal of the North American Benthological Society, 20(2), 280-286.

Barbour, M. T., Gerritsen, J., Snyder, B. D., \& Stribling, J. B. (1999). Rapid bioassessment protocols for use in streams and wadeable rivers: periphyton, benthic macroinvertebrates and fish. (EPA 841-B-99-002). Washington, D.C.: U.S. Environmental Protection Agency, Office of Water.

Beck, W. M., \& Beck, E. C. (1966). Chironomidae (Diptera) of Florida - I. Pentaneurini (Tanypodinae). Bulletin of the Florida State Museum, Biological Sciences Series, 10(8), 305-379.

Berger, W. H., \& Parker, F. L. (1970). Diversity of planktonic foraminifera in deep-sea sediments. Science, 168(3937), 1345-1347.

Boesch, D., Burreson, E., Dennison, W., Houde, E., Kemp, M., Kennedy, V., ... Ulanowicz, R. (2001). Factors in the Decline of Coastal Ecosystems. Science, 293(5535), 1589c-1591c.

Boesel, M. W. (1974). Observations on the Coelotanypodini of the Northeastern States, with Keys to the Known Stages (Diptera: Chironomidae: Tanypodinae). 
Journal of the Kansas Entomological Society, 47(4), 417-432.

Borkent, A. (1984). The systematics and phylogeny of the Stenochironomus complex (Xestochironomus, Harrisius, and Stenochironomus) (Diptera: Chironomidae). Memoirs of the Entomological Society of Canada, 128, 1-269.

Bouchard Jr., R. W., \& D. Huggins, J. K. (2005). A review of the issues related to taxonomic resolution in biological monitoring of aquatic ecosystems with an emphasis on macroinvertebrates. Retrieved from Lawrence, KS: http://biosurvey.ku.edu/sites/biosurvey.ku.edu/files/publishedworks/pdfs/KBSRept133 TaxResol.pdf

Bouchard Jr., R. W., \& Ferrington Jr., L. C. (2011). The effects of subsampling and sampling frequency on the use of surface-floating pupal exuviae to measure Chironomidae (Diptera) communities in wadeable temperate streams. Environmental Monitoring and Assessment, 181(1-4), 205-223.

Bricker, S. B., Longstaff, B., Dennison, W., Jones, A., Boicourt, K., Wicks, C., \& Woerner, J. (2008). Effects of nutrient enrichment in the nation's estuaries: A decade of change. Harmful Algae, 8(1), 21-32.

Caldwell, B. A. (1993). The immature stages of Ablabesmyia cinctipes (Johannsen) with comments on ecology. Spixiana, 16(1), 49-52.

Cañedo-Argüelles, M., Boix, D., Sánchez-Millaruelo, N., Sala, J., Caiola, N., Nebra, A., \& Rieradevall, M. (2012). A rapid bioassessment tool for the evaluation of the water quality of transitional waters. Estuarine, Coastal and Shelf Science, 111(0), 129-138.

Casas, J. J., \& Vilchez-Quero, A. (1996). Chironomid assemblages of three endoreic karstic lagoons (southern Spain) determined by collection of pupal exuviae: importance of the water mineralization and sediment characteristics. Internationale Revue der gesamten Hydrobiologie und Hydrographie, 81(4), 529-539.

Castillo, L. E., de la Cruz, E., \& Ruepert, C. (1997). Ecotoxicology and pesticides in tropical aquatic ecosystems of Central America. Environmental Toxicology and Chemistry, 16(1), 41-51.

Castillo, L. E., Martinez, E., Ruepert, C., Savage, C., Gilek, M., Pinnock, M., \& Solis, E. (2006). Water quality and macroinvertebrate community response following pesticide applications in a banana plantation, Limon, Costa Rica. Science of The Total Environment, 367(1), 418-432.

Castillo, L. E., Ruepert, C., \& Solis, E. (2000). Pesticide residues in the aquatic environment of banana plantation areas in the North Atlantic Zone of Costa Rica. Environmental Toxicology and Chemistry, 19(8), 1942-1950.
Chao, A. (1984). Non-parametric estimation of the number of classes in a population. Scandinavian Journal of Statistics, 11, 265-270.

Coffman, W. P., \& de la Rosa, C. (1998). Taxonomic composition and temporal organization of tropical and temperate assemblages of lotic Chironomidae. Journal of the Kansas Entomological Society, 71, 388-406.

Coffman, W. P., de la Rosa, C., Cumming, K., \& Wilzbach, M. A. (1992). Species richness in some Neotropical (Costa Rica) and Afrotropical (West Africa) lotic communities of Chironomidae (Diptera). Netherlands Journal of Aquatic Ecology, 26, 229-237.

Colbo, M. H. (1996). Chironomidae from marine coastal environments near St. John's, Newfoundland, Canada. Hydrobiologia, 318(1), 117-122. doi:10.1007/ bf00014137

Colwell, R. K. (2013). EstimateS: Statistical estimation of species richness and shared species from samples. Version 9. User's Guide and application published at: http://purl.oclc.org/estimates

Da Silva, F. L., Fonseca-Gessner, A. A., \& Ekrem, T. (2014). A taxonomic revision of genus Labrundinia Fittkau, 1962 (Diptera: Chironomidae: Tanypodinae). Zootaxa, 3769, 1-185.

De Oliveira, C. S. N., Da Silva, M. A. N., \& Gessner, A. A. F. (2013). Neotropical Ablabesmyia Johannsen (Diptera: Chironomidae, Tanypodinae)-Part I. 2013, 3733(1), 123.

Diepens, N. J., Pfennig, S., Van den Brink, P. J., Gunnarsson, J. S., Ruepert, C., \& Castillo, L. E. (2014). Effect of pesticides used in banana and pineapple plantations on aquatic ecosystems in Costa Rica. Journal of Environmental Biology, 35(1), 73-84.

Dimitriadis, S., \& Cranston, P. S. (2007). From the mountains to the sea: assemblage structure and dynamics in Chironomidae (Insecta: Diptera) in the Clyde River estuarine gradient, New South Wales, south-eastern Australia. Australian Journal of Entomology, 46(3), 188-197.

Donato, M., Siri, A., Massaferro, J., \& Brooks, S. J. (2015). Apedilum griseistriatum comb. nov., placement of Chironomus (Polypedilum) griseistriatum (Diptera, Chironomidae). Iheringia. Série Zoologia, 105, 5-11.

Downing, J. A., Mcclain, M., Twilley, R., Melack, J. M., Elser, J., Rabalais, N. N., ... Howarth, R. W. (1999). The impact of accelerating land-use change on the $\mathrm{N}$-Cycle of tropical aquatic ecosystems: Current conditions and projected changes. Biogeochemistry, 46(1), 109-148.

Echeverría-Sáenz, S., Mena, F., Pinnock, M., Ruepert, C., Solano, K., de la Cruz, E., ... Barata, C. (2012). Environmental hazards of pesticides from pineapple crop 
production in the Río Jiménez watershed (Caribbean Coast, Costa Rica). Science of The Total Environment, 440(0), 106-114.

Ekrem, T. (2007). A taxonomic revision of the genus Stempellinella (Diptera: Chironomidae). Journal of Natural History, 41(21-24), 1367-1465.

Epler, J. H. (1988). Biosystematics of the genus Dicrotendipes Kieffer, 1913 (Diptera: Chironomidae) of the world. Memoirs of the American Entomology Society, $36,1-214$.

Epler, J. H., \& Janetzky, W. J. (1998). A New Species of Monopelopia (Diptera: Chironomidae) from Phytotelmata in Jamaica, with Preliminary Ecological Notes. Journal of the Kansas Entomological Society, $71(3), 216-225$.

Fagan, M. E. (2014). The Changing Matrix: Reforestation and Connectivity in a Tropical Habitat Corridor. $(\mathrm{PhD})$, Columbia University.

Ferrington Jr., L. C. (2008). Global diversity of non-biting midges (Chironomidae; Insecta-Diptera) in freshwater. In E. V. Balian, C. Lévêque, H. Segers, \& K. Martens (Eds.), Freshwater animal diversity assessment (pp. 447-455). Netherlands: Springer Netherlands.

Ferrington Jr., L. C., Berg, M. B., \& Coffman, W. P. (2008). Chironomidae. In R. W. Merritt, K. W. Cummins, \& M. B. Berg (Eds.), An Introduction To The Aquatic Insects Of North America (4th ed., pp. 847-989). Dubuque, IA: Kendall/Hunt Publishing Company.

Ferrington Jr., L. C., Blackwood, M. A., Wright, C. A., Crisp, N. H., Kavanaugh, J. L., \& Schmidt, F. J. (1991). A protocol for using surface-floating pupal exuviae of Chironomidae for rapid bioassessment of changing water-quality. Sediment and Stream Water Quality in a Changing Environment: Trends and Explanation, 203, 181-190.

Ferrington Jr., L. C., Buzby, K. M., \& Masteller, E. C. (1993). Composition and Temporal Abundance of Chironomidae Emergence from a Tropical Rainforest Stream at El Verde, Puerto Rico. Journal of the Kansas Entomological Society, 66(2), 167-180.

Ferrington Jr., L. C., \& Saether, O. A. (2011). A revision of the genera Pseudosmittia Edwards, 1932, Allocladius Kieffer, 1913, and Hydrosmittia gen. n. (Diptera : Chironomidae, Orthocladiinae). Zootaxa, 2849, $1-314$

Gotelli, N. J., \& Colwell, R. K. (2011). Estimating species richness. In A. E. Magurran \& B. J. McGill (Eds.), Frontiers in measuring biodiversity. (pp. 39-54). New York: Oxford University Press.

Grant, P. B. C., Woudneh, M. B., \& Ross, P. S. (2013). Pesticides in blood from spectacled caiman (Caiman crocodilus) downstream of banana plantations in
Costa Rica. Environmental Toxicology and Chemistry, 32(11), 2576-2583.

Gutierrez-Fonseca, P. E., \& Lorion, C. M. (2014). Application of the BMWP-Costa Rica biotic index in aquatic biomonitoring: sensitivity to collection method and sampling intensity. Revista de Biología Tropical, 62(2), 275-289.

Herman, M. R., \& Nejadhashemi, A. P. (2015). A review of macroinvertebrate- and fish-based stream health indices. Ecohydrology \& Hydrobiology, 15(2), 53-67.

Hestenes, T. C., \& Saether, O. A. (2000). Three new Nearctic Thienemanniella Kieffer species with a review of the Nearctic species. Paper presented at the Late 20th Century Research on Chironomidae: an Anthology from the 13th International Symposium on Chironomidae, Aachen, Germany.

Hilsenhoff, W. L. (1977). Use of Arthropods to Evaluate Water Quality of Streams. Madison, Wisconsin: Department of Natural Resources.

Hilsenhoff, W. L. (1987). An improved biotic index of organic stream pollution. Great Lakes Entomologist, 20(1), 31-39.

Howarth, R., Chan, F., Conley, D. J., Garnier, J., Doney, S. C., Marino, R., \& Billen, G. (2011). Coupled biogeochemical cycles: eutrophication and hypoxia in temperate estuaries and coastal marine ecosystems. Frontiers in Ecology and the Environment, 9(1), $18-26$

Huang, D., \& Cheng, L. (2011). The flightless marine midge Pontomyia (Diptera: Chironomidae): ecology, distribution, and molecular phylogeny. Zoological Journal of the Linnean Society, 162(2), 443-456. doi:10.1111/j.1096-3642.2010.00680.x

Instituto Meteorológico Nacional. (2016). Climatic data: Limón (1941-2015). Retrieved from https://www. imn.ac.cr

Jacobsen, R. E. (2008). A Key to the Pupal Exuviae of the Midges (Diptera: Chironomidae) of Everglades National Park, Florida (Scientific Investigations Report 2008-5082). Retrieved from https://pubs. er.usgs.gov/publication/sir20085082

Jacobsen, R. E., \& Perry, S. A. (2000). A review of Beardius Reiss \& Sublette, with description of a new species from Everglades National Park, Florida (Insecta, Diptera, Chironomidae). Spixiana, 23, 129-144.

James, K. R., Cant, B., \& Ryan, T. (2003). Responses of freshwater biota to rising salinity levels and implications for saline water management: A review. Australian Journal of Botany, 51(6), 703-713.

Kafle, A. (2013). Chironomidae Contributions to the Macroinvertebrate Assemblage, Index of Biotic Integrity and Relationships to Water Quality Impairment 
for Eastern South Dakota Streams. (Master of Science), South Dakota State University.

Karr, J. R. (1981). Assessment of Biotic Integrity Using Fish Communities. Fisheries, 6(6), 21-27.

Karr, J. R., Fausch, K. D., Angermeier, P. L., Yant, P. R., \& Schlosser, I. J. (1986). Assessing biological integrity in running waters: A method and its rationale. Champaign, IL: Illinois Natural History Survey.

Kennish, M. J., \& Townsend, A. R. (2007). Nutrient Enrichment and Estuarine Eutrophication. Ecological Applications, 17(5), S1-S2.

King, R. S., \& Richardson, C. J. (2002). Evaluating subsampling approaches and macroinvertebrate taxonomic resolution for wetland bioassessment. Journal of the North American Benthological Society, 21(1), 150-171.

Kranzfelder, P. (2012). Comparison of emergence and taxanomic composition of Chironomidae (Insecta: Diptera) in Tortuguero National Park, Costa Rica. (Master's Thesis), University of Minnesota, University of Minnesota.

Kranzfelder, P., Anderson, A. M., Egan, A. T., Mazack, J. E., Bouchard, R. W., \& Ferrington, L. C. (2015). Use of Chironomidae (Diptera) surface-floating pupal exuviae as a rapid bioassessment protocol for water bodies. Journal of Visualized Experiments (JoVE), 101, e52558.

Kranzfelder, P., Corcoran, J. M., Rampi, L. P., Knight, J. F., \& Ferrington, L. C. (in review). Land use and land cover change in six watersheds on the Caribbean coast of Costa Rica with implications for estuarine monitoring. Journal of Coastal Conservation.

Kranzfelder, P., Ekrem, T., \& Stur, E. (2017). DNA barcoding for species identification of insect skins: A test on Chironomidae (Diptera) pupal exuviae. Journal of Insect Science, 17(6), 1-7.

Kranzfelder, P., \& Ferrington Jr., L. C. (2016). Temporal and spatial variability of Chironomidae (Insecta: Diptera) species emergence in a Neotropical estuary. Freshwater Science, 35(2), 631-643.

Kress, N., Coto, S. L., Brenes, C. L., Brenner, S., \& Arroyo, G. (2002). Horizontal transport and seasonal distribution of nutrients, dissolved oxygen and chlorophyll-a in the Gulf of Nicoya, Costa Rica: A tropical estuary. Continental Shelf Research, 22(1), 51-66.

Langton, P. H. (1991). A key to pupal exuviae of West Palearctic Chironomidae. Huntingdon, Cambridgeshire, England: P. H. Langton.

Lenat, D. R., \& Resh, V. H. (2001). Taxonomy and stream ecology - The benefits of genus- and specieslevel identifications. Journal of the North American Benthological Society, 20(2), 287-298.
Lindegaard, C. (1989). A review of secondary production of zoobenthos in freshwater ecosystems with special reference to Chironomidae (Diptera). Acta Biologica Debrecen, Oecologica Hungarica, 3, 231-240.

Lovelock, C. E., Feller, I. C., McKee, K. L., Engelbrecht, B. M. J., \& Ball, M. C. (2004). The effect of nutrient enrichment on growth, photosynthesis and hydraulic conductance of dwarf mangroves in Panamá. Functional Ecology, 18(1), 25-33.

Lunde, K. B., \& Resh, V. H. (2012). Development and validation of a macroinvertebrate index of biotic integrity (IBI) for assessing urban impacts to Northern California freshwater wetlands. Environmental Monitoring and Assessment, 184(6), 3653-3674.

Magurran, A. E., \& McGill, B. J. (2011). Biological Diversity: Frontiers in Measurement and Assessment: OUP Oxford.

Maue, T., \& Springer, M. (2008). Effect of methodology and sampling time on the taxa richness of aquatic macroinvertebrates and subsequent changes in the water quality index from three tropical rivers, Costa Rica. Revista de Biología Tropical, 56(4), 257-271.

Mendes, H. F., Marcondes, C. B., \& Pinho, L. C. D. (2003). A new phytotelmatic species of Monopelopia Fittkau, 1962 (Insecta: Diptera: Chironomidae: Tanypodinae) from South Brazil. Zootaxa, 262, 1-10.

Ministerio del Ambiente y Energia y la Ministra de Salud. (2007). Reglamento Reglamento para la Evaluación y Clasificación de la Calidad de Cuerpos de Agua Superficiales No. 33903-MINAE-S. La Gaceta, 178.

Nicacio, G., \& Juen, L. (2015). Chironomids as indicators in freshwater ecosystems: an assessment of the literature. Insect Conservation and Diversity, 8(5), 393-403.

Nixon, S. W. (1995). Coastal marine eutrophication: A definition, social causes, and future concerns. Ophelia, 41(1), 199-219.

Oliveira, C. S. N. D., Mendes, H. F., \& Silva, M. A. N. D. (2010). A New Species Of The Genus Monopelopia From South Brazil, With Keys To The Neotropical - Nearctic Species (Diptera: Chironomidae: Tanypodinae). Zootaxa, 2420, 53-62.

Oliveira, C. S. N. D., \& Silva, F. L. (2011). Two new species of Larsia Fittkau, 1962 (Diptera: Chironomidae: Tanypodinae) from Neotropical Region, with a checklist of Larsia species of the world. Zootaxa $2786,27-41$.

Paerl, H. W., Hall, N. S., Peierls, B. L., \& Rossignol, K. L. (2014). Evolving Paradigms and Challenges in Estuarine and Coastal Eutrophication Dynamics in a Culturally and Climatically Stressed World. Estuaries and Coasts, 37(2), 243-258. 
Paggi, A. C. (1977). Imaginal and preimaginal forms of chironomids (Diptera) II. Parachironomus longistilus sp. nov. Limnobios, 1(6).

Palmégn, E., \& Lindeberg, B. (1959). The Marine Midge, Clunio Marinus Hal. (Dipt., Chironomidae), Found in Brackish Water In The Northern Baltic. Internationale Revue der gesamten Hydrobiologie und Hydrographie, 44(1-4), 383-394. doi:doi:10.1002/ iroh. 19590440120

Pinder, L. C. V. (1986). Biology of freshwater Chironomidae. Annual Review of Entomology, 31, 1-23.

Pringle, C. M., Anderson, E. P., Ardón, M., Bixby, R. J., Connelly, S., Duff, J. H., ... Triska, F. J. (2016). Rivers of Costa Rica. In M. Kappelle (Ed.), Costa Rican Ecosystems (pp. 621-655). Chicago: University of Chicago Press.

Pringle, C. M., \& Hamazaki, T. (1998). The role of omnivory in a Neotropical stream: separating diurnal and nocturnal effects. Ecology, 79(1), 269-280.

Rizo-Patrón V, F., Kumar, A., McCoy Colton, M. B., Springer, M., \& Trama, F. A. (2013). Macroinvertebrate communities as bioindicators of water quality in conventional and organic irrigated rice fields in Guanacaste, Costa Rica. Ecological Indicators, 29, 68-78.

Roback, S. S. (1980). The immature chironomids of the eastern United States IV. Tanypodinae-Procladiini. Proceedings of the Academy of Natural Sciences of Philadelphia, 132, 1-63.

Roback, S. S. (1986). The Immature Chironomids of the Eastern United States. VII. Pentaneurini-Genus Monopelopia, with Redescription of the Male Adults and Description of Some Neotropical Material. Proceedings of the Academy of Natural Sciences of Philadelphia, 138(2), 350-365.

Roback, S. S., \& Coffman, W. P. (1983). Results of the Catherwood Bolivian- Peruvian Altiplano Expedition part II. Aquatic Diptera including montane Diamesinae and Orthocladiinae (Chironomidae) from Venezuela. Proceedings of the Academy of Natural Sciences of Philadelphia, 135, 9-79.

Rosenberg, D. (1992). Freshwater biomonitoring and Chironomidae. Netherland Journal of Aquatic Ecology, 26(2-4), 101-122.

Ruse, L. (2002). Chironomid pupal exuviae as indicators of lake status. Archiv fur Hydrobiologie, 153(3), 367-390.

Ruse, L. (2010). Classification of nutrient impact on lakes using the chironomid pupal exuvial technique. Ecological Indicators, 10(3), 594-601.

Sæther, O., \& Cranston, P. (2012). New World Stictocladius Edwards (Diptera: Chironomidae). Neotropical Entomology, 41(2), 124-149.
Saether, O. A. (2011). Notes On Canadian Ablabesmyia Johannsen, With Keys To Known Nearctic Immatures Of The Genus (Diptera: Chironomidae). Zootaxa.

Sæther, O. A. (2004). A Review of Orthocladius subgen. Symposiocladius Cranston (Diptera: Chironomidae). Aquatic Insects, 25(4), 281-317.

Sawedal, L. (1984). The cururui-group of the genus Stempellina Thienemann \& Bause. Amazonian Tanytarsini II. (Diptera: Chironomidae). Entomologica Scandinavica, 15, 141-149.

Serrano, M. A. S., \& Nolte, U. (1996). A sit-and-wait predatory chironomid from tropical Brazil- Fittkauimyia crypta sp. n. (Diptera: Chironomidae). Insect Systematics \&amp; Evolution, 27(3), 251-258.

Shapiro, J., Lamarra, V. A., \& Lynch, M. (1975). Biomanipulation: An Ecosystem Approach to Lake Restoration: Limnological Research Center, University of Minnesota.

Silva, F. L. D., \& Ekrem, T. (2016). Phylogenetic relationships of nonbiting midges in the subfamily Tanypodinae (Diptera: Chironomidae) inferred from morphology. Systematic Entomology, 41(1), 73-92.

Siqueira, T., De Oliveira Roque, F., \& Trivinho-Strixino, S. (2008). Phenological patterns of neotropical lotic chironomids: Is emergence constrained by environmental factors? Austral Ecology, 33(7), 902-910.

Soponis. (1987). Paranilothauma and Neelamia, New Genera of Chironomini (Diptera: Chironomidae) from Brazil. Studies on Neotropical Fauna and Environment, 22(1), 11-24.

Souza, M., Moulton, T., Silveira, R., Krsulovic, F., \& Brito, E. (2007). Responses of Chironomidae (Diptera; Insecta) to the exclusion of shrimps and Ephemeroptera in a coastal forest stream, Rio de Janeiro, Brazil. Brazilian Journal of Biology, 67, 47-51.

Spies, M., Andersen, T., Epler, J. H., \& Watson, C. N. (2009). Chironomidae (non-biting midges). In B. V. Brown (Ed.), Manual of Central American Diptera (Vol. 1, pp. 437-480). Ottawa: NRC Research Press.

Spies, M., \& Reiss, F. (1996). Catalog and bibliography of Neotropical and Mexican Chironomidae (Insecta, Diptera). Spixiana Supplement, 22, 61-119.

Stein, H., Springer, M., \& Kohlmann, B. (2008). Comparison of two sampling methods for biomonitoring using aquatic macroinvertebrates in the Dos Novillos River, Costa Rica. Ecological Engineering, 34(4), 267-275.

Sublette, J. E., \& Sasa, M. (1994). Chironomidae collected in Onchocerciasis endemic areas of Guatemala (Insecta, Diptera). Spixiana Supplement, 20, 1-60. 
Tang, H. (2016). Paralauterborniella from Oriental China (Diptera: Chironomidae). Oriental Insects, 50(4), 160-170.

Tejerina, E. G., \& Paggi, A. C. (2009). A new Neotropical species of Oliveiriella Wiedenbrug \& Fittkau (Diptera: Chironomidae) from Argentina, with description of all its life stages. Aquatic Insects, 31(2), 91-98.

Thorne, R., \& Williams, P. (1997). The response of benthic macroinvertebrates to pollution in developing countries: a multimetric system of bioassessment. Freshwater Biology, 37(3), 671-686.

Trivinho-Strixino, S., Da Silva, F. L., \& Roque, F. O. (2010). A new species of Parachironomus Lenz, 1921 (Diptera: Chironomidae: Chironominae), and description of immature stages of two other species from the Neotropical Region. Zootaxa, 2689, 1-14. doi:10.5281/zenodo. 199500

Watson, C. N., \& Heyn, M. W. (1992). A preliminary survey of the Chironomidae (Diptera) of Costa Rica, with emphasis on the lotic fauna. Netherland Journal of Aquatic Ecology, 26(2-4), 257-262.

Weisberg, S. B., Ranasinghe, J. A., Dauer, D. M., Schaffner, L. C., Diaz, R. J., \& Frithsen, J. B. (1997). An estuarine benthic index of biotic integrity (B-IBI) for Chesapeake Bay. Estuaries, 20(1), 149.

Wiedenbrug, S., \& Andersen, T. (2002). New Species of Parakiefferiella Thienemann, 1936 from South America (Chironomidae, Orthocladiinae). Studies on Neotropical Fauna and Environment, 37(2), 119-132.

Wiedenbrug, S., \& Fittkau, E. J. (1997). Oliveiriella almeidai (Oliveira, 1946), gen. nov., comb. nov., from South America with description of the pupae (Insecta, Diptera, Chironomidae, Orthocladiinae). Spixiana, 20, 167-172.

Wiedenbrug, S., Lamas, C. E., \& Trivinho-Strixino, S. (2012). A review of the genus Corynoneura Winnertz (Diptera: Chironomidae) from the Neotropical region. Zootaxa, 3574, 1-61.
Wiedenbrug, S., \& Ospina-Torres, R. (2005). A key to pupal exuviae of Neotropical Tanytarsini (Diptera: Chironomidae). Amazoniana, 18(3), 317-371.

Wiedenburg, S., Lamas, C. E., \& Trivinho-Strixino, S. (2013). A review of Neotropical species in Thienemanniella Kieffer (Diptera, Chironomidae). Zootaxa, $3670,215-237$.

Wiedenburg, S., Mendes, H. F., Pepinelli, M., \& TrivinhoStrixino, S. (2009). Review of the genus Onconeura Andersen et Sæther (Diptera: Chironomidae), with the description of four new species from Brazil. Zootaxa, 2265, 1-26.

Wiedenburg, S., \& Trivinho-Strixino, S. (2009). Ubatubaneura, a new genus of the Corynoneura group (Diptera: Chironomidae: Orthocladiinae) from the Brazilian Atlantic Forest. Zootaxa, 1993, 41-52.

Wiedenburg, S., \& Trivinho-Strixino, S. (2011). New species of the genus Corynoneura Winnertz (Diptera, Chironomidae) from Brazil. Zootaxa, 2822, 1-40.

Wiederholm, T. (1986). Chironomidae of the Holarctic region. Part 2. Pupae (Vol. 28). Sandby, Sweden: Entomologica Scandinavica Supplement.

Williams, D. D., \& Hamm, T. (2002). Insect community organisation in estuaries: the role of the physical environment. Ecography, 25(3), 372-384.

Williams, D. D., \& Williams, N. E. (1998). Aquatic insects in an estuarine environment: densities, distribution and salinity tolerance. Freshwater Biology, 39(3), 411-421.

Williams, W. D. (1998). Salinity as a determinant of the structure of biological communities in salt lakes. Hydrobiologia, 381(1-3), 191-201.

Wilson, R. S., \& Ruse, L. P. (2005). A guide to the identification of genera of chironomid pupal exuviae occurring in Britain and Ireland (including common genera from Northern Europe) and their use in monitoring lotic and lentic fresh waters. Ambleside, Cumbria, UK.: Freshwater Biological Association. 